\title{
GAMBARAN KARAKTERISTIK IBU HAMIL DENGAN RISIKO PREEKLAMPSIA (Studi Di Puskesmas Kabupaten Majalengka)
}

\author{
Mamlukah, Ade Saprudin \\ Sekolah Tinggi Ilmu Kesehatan Kuningan Garawangi
}

lulu.3972@yahoo.com

\begin{abstract}
Abstrak
Angka Kejadian komplikasi hipertensi pada kehamilan berkisar antara 12-22\% dengan akibat yang bervariasi, dari ringan sampai berat. Hipertensi pada kehamilan merupakan penyebab morbiditas dan mortalitas neonatal serta, bertanggung jawab terhadap 17,6\% kematian maternal, bahkan menjadi penyebab ke-3 kematian ibu setelah tromboembolisme dan hemoragik. Gangguan hipertensi dalam kehamilan menjadi penyulit sekitar $8 \%$ dari seluruh kehamilan. Salah satu jenis hipertensi pada kehamilan adalah preeclampsia. Kabupaten Majalengka merupakan kabupataen yang angka preeklamsianya cukup tinggi pada tahun 2016 mencapai 50\% sebagai penyumbang AKI dari tahun sebelumya yang hanya $45 \%$, kemudian perdarahan $30 \%$, infeksi $5 \%$ dan sisanya $20 \%$ karena penyebab tidak langsung..

Penelitian dilakukan di Puskesmas kabupaten Majalengka yang terpilih sebagai sampel . Penelitian dilakukan dengan tahap: 1) pemilihan sampel dari populasi seluruh ibu hamil trimester dua yang mempunyai resiko preeklapsia, dengan teknik cluster sampling atau area sampling. Kemudian sampel dibagi menjadi 2 kelompok sebagai kelompok perlakuan (10 orang) dan kelompok kontrol (10 orang), Desain penelitian ini mengguanakan rancangan). Jenis penelitian yang digunakan adalah penelitian yang bersifat deskriptif, yang menggambarkan karakteristik ibu hamil dengan risiko preeklampsia di Puskesmas Kabupaten Majalengka.

Sebagian besar $70 \%$ ada di kelompok umur 25-35 tahun, pendidikan sebagian besar $65 \%$ ada pada kelompok pendidikn rendah, status bekerja sebagian besar berada pada kelompok ibu tidak bekerja sebanyak $75 \%$, pendapatan setengahnya $50 \%$ pada kelompok pendapatan < 1.5 Juta, untuk status paritas sebagian besar $60 \%$ ada pada kelompok multipara, untuk rata-rata tekanan sistolik 106,5 dan tekanan diastoliknya rata-rata 67,5, untuk kecemasan sebagian besar $70 \%$ ada pada kondisi kecemasan yang berat, sedangkan proteinuria sebagian besar sebanyak $75 \%$ ada dalam kondisi proteinuria yang negatif.
\end{abstract}

Kata Kunci: Terapi murattal al-Quran, Risiko preeklampsi, tingkat kecemasan, proteinuria, tekanan darah.

\section{Latar Belakang}

Stres selama kehamilan secara langsung atau tidak langsung dapat menyebabkan peningkatan komplikasi kehamilan. Tingkat tumor nekrosis faktoralfa dan sitokin interleukin-6 pro-inflamasi nampak lebih tinggi pada wanita yang mengalami stres selama kehamilan. Di sisi lain, kadar interleukin-10 (IL-10) 
berpasangan, yang memainkan peran penting dalam kehamilan normal, berkurang pada wanita dengan preeklampsia. Juga, tingkat kortikotropin meningkat dan ada peningkatan aktivitas pada sistem saraf simpatik ( SNS ), yang merupakan perubahan yang disebabkan oleh stres, dapat diamati pada wanita dengan preeklampsia. (Vollebregt et al., 2008, Moafi et al., 2013). Aspek psikologis mengarah padaaktivasi SNS berlebihan karena stimulasi sistem saraf otonom yang merupakan faktor risiko untuk preeklampsia.(Kharaghani et al., 2012) Penelitian sebelumnya menunjukkan bahwa gejala kecemasan atau depresi terkait dengan hasil kehamilan yang merugikan, seperti kelahiran prematur, berat badan lahir kurang dari 2500 gram, dan lingkar kepala yang kecil, (Rezaee and Framarzi, 2014) namun, ada beberapa penelitian yang meneliti hubungan antara faktor psikologis dan preeklampsia.Beberapa penelitian telah menunjukkan hubungan positif antara faktor psikologis ibu dan preeklampsia (Kharaghani et al., 2012). Depresi dan kecemasan selama kehamilan, karena perubahan sekresi hormon vasoaktif atau pemancar neuroendokrinlainnya, dapat menyebabkan peningkatan risiko hipertensi gestasional. (Kurki et al., 2000)' mereka memiliki kedua faktor tersebut, risiko preeklampsia meningkat 3.1 kali lipat. Menurut penelitian tersebut, depresi dan kecemasan selama awal kehamilan dikaitkan dengan risiko preeklampsia.(Kurki et al., 2000) Vasokonstriksi pada preeklampsia dapat terjadi pada awal kehamilan dan hasil dalam peningkatan resistensi vaskuler uterus pada ibu yang cemas, dapat menjadi penyebab preeklampsia.(Alipour et al., 2006)

Teknik relaksasi pada ibu hamil yang melibatkan unsur spiritualitas ibu masih jarang dilakukan, padahal faktor spiritual adalah faktor penting yang juga mempengaruhi proses penyembuhan dan intervensi psikologis. (Burke et al., 2004,
Hawari, 2005). Salah satu Teknik relaksasi yang melibatkan unsur spiritual adalah dengan Terapi Murattal Alquran, yaitu mendengarkan lantunan ayat suci AlQur'an dengan irama sedang, tidak terlalu lambat dan tidak terlalu cepat (tartil). Beberapa penelitian menunjukkan hubungan antara coping religius dengan kecemasan yang turut menunjukkan pentingnya unsur spiritual dan religius dalam penanganan kecemasan.(Blume, 2006, Tarakeshwar et al., 2005, Tepper et al., 2001) Murattal Al-Quran juga merupakan Dzikir yang utama,Dzikir akan membuat seseorang merasa tenang sehingga kemudian menekan kerja sistem syaraf simpatetis dan mengaktifkan kerja sistem syaraf parasimpatetis.(Sholeh, 2006) Terapi Murattal Al-Quran diharapkan meningkatkan ketenangan dan ketentraman hati, kesabaran, pengendalian diri, ungkapan rasa syukur,dan ikhlas, sehingga memperbaiki emosi pada ibu yang tidak berhasil menyesuaikan diri terhadap perubahan kehamilan Peningkatan emosi positif mempengaruhi sekresi CRF oleh hipotalamus, sehingga akan mengendalikan sekresi ACTH oleh HPA, dan dengan demikian kadar kortisol dalam darah akan menurun. Penurunan kadar kortisol memodulasi respon immune pada ibu hamil.

\section{Metode Penelitian}

Jenis penelitian yang digunakan adalah penelitian yang bersifat deskriptif, yang menggambarkan karakteristik ibu hamil dengan risiko preeklampsia di Puskesmas Kabupaten Majalengka.

\section{Populasi dan Sampel}

Populasi dalam penelitian ini adalah ibu hamil dengan risiko preeklampsia di Puskesmas Kabupaten Majalengka. Sampel dalam penelitian ini adalah ibu hamil 
dengan risiko preeklampsia di Puskesmas Kabupaten Majalengka yang memenuhi kriteri inklusi. Puskes Terdapat ibu hamil dengan risiko preeklampsi di puskesmas kabupaten majalengka adalah sebagian besar $70 \%$ ada di kelompok umur 25-35 tahun, untuk pendidikan sebagian besar 65 $\%$ ada pada kelompok pendidikn rendah, untuk status bekerja sebagian besar berada pada kelompok ibu tidak bekerja sebanyak $75 \%$, untuk pendapatan setengahnya $50 \%$ pada kelompok pendapatan $<1.5$ Juta,dan setengahnya $50 \%>1.5$ juta, untuk status paritas sebagian besar $60 \%$ ada pada kelompok multipara, untuk rata-rata tekanan sistolik 106,5 dan tekanan diastoliknya rata-rata 67,5 , untuk kecemasan sebagian besar $70 \%$ ada pada kondisi kecemasan yang berat, sedangkan proteinuria sebagian besar sebanyak $75 \%$ ada dalam kondisi proteinuria yang negatif.

Terdapat ibu hamil dengan risiko preeklampsi di Puskesmas Kabupaten Majalengka adalah sebagian besar $70 \%$ ada di kelompok umur 25-35 tahun, untuk pendidikan sebagian besar $65 \%$ ada pada kelompok pendidikn rendah, untuk status bekerja sebagian besar berada pada kelompok ibu tidak bekerja sebanyak $75 \%$, untuk pendapatan setengahnya $50 \%$ pada kelompok pendapatan < 1.5 Juta,dan setengahnya $50 \%>1.5$ juta, untuk status paritas sebagian besar $60 \%$ ada pada kelompok multipara, untuk rata-rata tekanan sistolik 106,5 dan tekanan diastoliknya rata-rata 67,5 , untuk kecemasan sebagian besar $70 \%$ ada pada kondisi kecemasan yang berat, sedangkan proteinuria sebagian besar sebanyak $75 \%$ ada dalam kondisi proteinuria yang negatif.

Terdapat ibu hamil dengan risiko preeklampsi di puskesmas kabupaten majalengka adalah sebagian besar $70 \%$ ada di kelompok umur 25-35 tahun, untuk pendidikan sebagian besar $65 \%$ ada pada kelompok pendidikn rendah, untuk status bekerja sebagian besar berada pada kelompok ibu tidak bekerja sebanyak $75 \%$, untuk pendapatan setengahnya $50 \%$ pada kelompok pendapatan $<1.5$ Juta,dan setengahnya $50 \%>1.5$ juta, untuk status paritas sebagian besar $60 \%$ ada pada kelompok multipara, untuk rata-rata tekanan sistolik 106,5 dan tekanan diastoliknya rata-rata 67,5 , untuk kecemasan sebagian besar $70 \%$ ada pada kondisi kecemasan yang berat, sedangkan proteinuria sebagian besar sebanyak $75 \%$ ada dalam kondisi proteinuria yang negatif. Puskesmas yang dijadikan sebagai tempat penelitian ditentukan pengambilan sampelnya dengn teknik cluster sampling atau area sampling,.Sebagai kriteria inklusi adalah :Muslim, trimester 2, primipara, kehamilan ganda, usia < 20 atau > 35 tahun, riwayat pre-eklampsia/eklampsia pada kehamilan sebelumnya, riwayat dalam keluarga pernah menderita, hipertensi, preeklampsia ,penyakit ginjal, hipertensi dan diabetes melitus yang sudah ada sebelum kehamilan, obesitas, bersedia menjadi responden dalam penelitian, sadar serta dapat diajak komunikasi secara aktif. Kriteria eksklusi .dalam penelitian ini adalah : ibu tidak sedang menderita penyakit berat dan didiagnosis menderita preklampsia/eklampsia.

Instrumen penelitian ini berupa kuesioner. Kuesioner memuat daftar pertanyaan, pemeriksaan tekanan darah dan pemeriksaan proteinuria.

\section{Hasil dan Pembahasan}

Pada penelitian ini ada 9 karakteristik yang dikendalikan yaitu umur, pendidikan, pekerjaan, pendapatan dan paritas, tekanan darah sistolik, tekanan darah diastolik, kecemasan, dan kadar proteinuria, dengan cara mencari beda rerata pada tiap kelompok perlakuan dan kontrol.dan karakteristik responden semua kelompok disajikan dalam tabel berikut

\section{Tabel 1. Sebaran data karakteristik berdasarkan kelompok intervensi}




\begin{tabular}{|c|c|c|}
\hline Karakteristik & Jumlah & Prosentase \\
\hline Sampel, n & 20 & \\
\hline \multicolumn{3}{|l|}{ Usia } \\
\hline$-<20$ atau $>35$ tahun, $n(\%)$ & 6 & 30 \\
\hline - 25-35 tahun, $\mathrm{n}(\%)$ & 14 & 70 \\
\hline \multicolumn{3}{|l|}{ Pendidikan } \\
\hline - Rendah (SD-SMP), n (\%) & 13 & 65 \\
\hline - Tinggi (SMA - PT), n (\%) & 7 & 35 \\
\hline \multicolumn{3}{|l|}{ Status Bekerja, n (\%) } \\
\hline - Tidak bekerja, n (\%) & 15 & 75 \\
\hline - Bekerja, n (\%) & 5 & 25 \\
\hline \multicolumn{3}{|l|}{ Pendapatan, n (\%) } \\
\hline$-<1.5$ Juta, n (\%) & 10 & 50 \\
\hline - >1.5 Juta, n $(\%)$ & 10 & 50 \\
\hline \multicolumn{3}{|l|}{ Status Paritas, $\mathrm{n}(\%)$} \\
\hline - Primipara, n (\%) & 8 & 40 \\
\hline - Multipara, n (\%) & 12 & 60 \\
\hline - Granmultipara, n (\%) & 0 & 0 \\
\hline Tekanan Sistolik, rata-rata & 106,5 & - \\
\hline Tekanan Diastolik, rata-rata & 67,5 & - \\
\hline \multicolumn{3}{|l|}{ Kecemasan, n (\%) } \\
\hline - Sangat berat, n (\%) & 2 & 10 \\
\hline - Berat, n (\%) & 14 & 70 \\
\hline - Sedang, n (\%) & 3 & 15 \\
\hline - Ringan, n (\%) & 1 & 5 \\
\hline \multicolumn{3}{|l|}{ Proteinuri, n (\%) } \\
\hline - Positif, n (\%) & 5 & 25 \\
\hline - Negatif, n (\%) & 15 & 75 \\
\hline
\end{tabular}

Dari table 1 di dapatkan sebagian besar umuribu hamil dengan risiko preeklampsi di puskesmas kabupaten majalengka adalah sebagian besar $70 \%$ ada di kelompok umur 25-35 tahun, untuk pendidikan sebagian besar $65 \%$ ada pada kelompok pendidikn rendah, untuk status bekerja sebagian besar berada pada kelompok ibu tidak bekerja sebanyak $75 \%$, untuk pendapatan setengahnya $50 \%$ pada kelompok pendapatan < 1.5 Juta,dan setengahnya $50 \%>1.5$ juta, untuk status paritas sebagian besar $60 \%$ ada pada kelompok multipara, untuk rata-rata tekanan sistolik 106,5 dan tekanan diastoliknya rata-rata 67,5 , untuk kecemasan sebagian besar $70 \%$ ada pada kondisi kecemasan yang berat, sedangkan proteinuria sebagian besar sebanyak $75 \%$ ada dalam kondisi proteinuria yang negatif.

\section{Umur}

Hasil penelitian di Puskesmas Kabupaten Majalengka menunjukkan bahwa ibu hamil dengan risiko preklampsia pada ibu hamil Hasil ini menunjukkan bahwa mayoritas pre eklampsia terjadi pada umur kehamilan < 20 atau > 35 tahun sebanyak $30 \%$ dan yang kelompok umur 25-35 tahun sebanyak $70 \%$. Hasil penelitian ini sesuai dengan teori bahwa semakin tua masa kehamilan hampir semua organ tubuh bekerja lebih berat dari biasanya karena beban kehamilan sehingga resiko 
komplikasi kehamilan seperti preeklampsia meningkat.(Manuaba, 2010) Ibu dengan usia resiko kehamilan menunjukkan bahwa fungsi organ reproduksi yang sudah tidak maksimal atau tidak siap dalam menghadapi kehamilan, hal ini akan berpengaruh terhadap kehamilan dan ibu sangat beresiko mengalami berbagai komplikai kehamilan salah satunya adalah preeklampsia, dimana ketidakmampuan system tubuh dapat meningkatkan tekanan darah ibu, dan menyebabkan retensi cairan. Umur merupakan salah satu faktor yang menentukan status kesehatan ibu hamil. Akan tetapi pada kasus preklampsia umur tidak menjadi satu-satunya faktor resiko kemunculan preeklampsia, melainkan ada faktor lain seperti nulipara, lingkungan, kondisi sosial ekonomi, seasonal influences, obesitas, kehamilan ganda, usia ibu, hiperhomocysteinemia, gangguan metbaolis dan preeklampsia pada kehamilan sebelumnya.(Cunningham, 2010) Banyaknya preeklampsia yang terjadi pada rentang usia sehat dikarenakan proses kehamilan dan persalinan paling banyak terjadi pada usia produktif 20-35 tahun. Rata-rata pasien preeklampsia yang meninggal ada pada rentang usia 20-39 tahun, dengan rata-rata usia 28,2 tahun. Namun demikian, adanya data yang menunjukkanbahwa hampir separuh responden preeklampsia berusia resiko tinggi juga harus diperhatikan. Usia ibu berkaitan erat dengan sistem kekebalan tubuh, fungsi sel, serta berkaitan dengan kemampuan ibu dalam memberikan nutrisi dan oksigenasi kepada janin yang dikandung. Sebagian masalah kesehatan adalah berkaitan dengan usia. (Khusen, 2016).

\section{Pendidikan}

Ibu hamil yang berisiko preeklampsia di puskesmas Kabupaten Majalengka untuk pendidikan sebagian besar $65 \%$ ada pada kelompok pendidikn rendah, dan $35 \%$ ada pada kelompok pendidikan tinggi . Pendidikan berkaitan dengan daya akses dan daya tangkap seseorang terhadap informasi kesahatan. Pendidikan juga berkaitan dengan kesadaran seseorang akan pentingnya perilaku hidup sehat. Tingkat pendidikan seseorang mempengaruhi bagaimana seorang mengambil keputusan atas masalah kesehatan yang dialaminya. Semakin rendah pendidikan ibu maka akan semakin sedikit keinginan memanfaatkan pelayanan kesehatan. ibu dengan pendidikan tinggi dan yang bekerja di sektor formal mempunyai akses yang lebih baik terhadap informasi tentang kesehatan, lebih aktif menentukan sikap dan lebih mandiri mandiri mengambil tindakan perawatan.(Khuzaiyah et al., 2016). Pendidikan berkaitan dengan daya akses dan daya tangkap seseorang terhadap informasi kesahatan. Pendidikan juga berkaitan kesadaran seseorang akan pentingnya perilaku hidup sehat. Tingkat pendidikan seseorang mempengaruhi bagaimana seorang mengambil keputusan atas masalah kesehatan yang dialaminya. Semakin rendah pendidikan ibu maka akan semakin sedikit keinginan memanfaatkan pelayanan kesehatan ibu dengan pendidikan tinggi dan yang bekerja di sektor formal mempunyai akses yang lebih baik terhadap informasi tentang kesehatan, lebih aktif menentukan sikap dan lebih mandiri mengambil tindakan perawatan. (Padila, 2014)

\section{Pendapatan}

Untuk karakteristik pendapatan setengahnya $50 \%$ pada kelompok pendapatan < 1.5 Juta, dan setengahnya 50 $\%>1.5$ juta. hal ini menunjukkan hampir sama dan sebanding besar ibu hamil beresiko preeklampsia dari segi pemenuhan kebutuhan hidup sehari-hari dan Pendapatan diperlukan ibu hamil dalam menyediakan dana yang diperlukan untuk memenuhu kebutuhannya dan persiapan dalam menjelang persalinan dan pemenuhan kebutuhan untuk bayinya, Pendapatan adalah hasil pencaharian (usaha 
JURNAL ILMU KESEHATAN BHAKTI HUSADA:

HeAlth SCIENCES JOURNAL, Vol. 09 No. 02, DeSEMBER 2018

DOI: https://doi.org/10.34305/jikbh.v9i2.62 dan sebagainya) sesuatu yang didapatkan (dibuat dan sebagainya) yang sedianya belum ada dan sangat besar manfaatnya bagi kehidupan manusia. Dalam memenuhi kebutuhan primer maupun kebutuhan sekunder keluarga dengan status ekonomi baik lebih mudah, memenuhi kebutuhan sehari-hari dibandingkan keluarga dengan status ekonomi rendah. Hal ini akan mempengaruhi kebutuhan informasi yang termasuk kebutuhan sekunder.

\section{Paritas}

Untuk status paritas sebagian besar $60 \%$ ada pada kelompok multipara dan 40 $\%$ pada kelompok primipara. Ibu primipara lebih beresiko mengaami pre eklampsia atau lebih dikenal dengan keracunan kehamilan sering terjadi hal ini dikarenakan antibody ibu tidak sempurna menerima antigen plasenta hal ini dikarenakan ini adalah proses pertama dalam tubuh mengalami kehamilan. Pre-eklampsia sering terjadi pada kehamilan pertama dan tidak timbul lagi pada kehamilan berikutnya. Hal ini dapat diterangkan bahwa pada kehamilan pertama pembentukan blocking antibodies terhadap antigen plasenta tidak sempurna, yang semakin sempurna pada kehamilan berikutnya. Faktor resiko preeklampsia adalah nulipara, lingkungan, kondisi sosial ekonomi, seasonal influences, obesitas, kehamilan ganda, usia ibu, hiperhomocysteinemia, gangguan metabolis dan preeklampsia pada kehamilan sebelumnya.(Cunningham et al., 2014) . Primigravida (nulipara) memiliki peluang sebesar 3 kali terkena preeklampsia dibandingkan dengan yang bukan primigravida. Masing-masing faktor memberikan risiko yang berbeda-beda (HKFM, 2016, Duley et al., 2006).

\section{Tekanan darah}

Untuk rata-rata tekanan sistolik pada ibu hamil dengan risiko preeklampsia di puskesmas Kabupaten Majalengka 106,5 dan tekanan diastoliknya rata-rata 67,5. Untuk tekanan darah ibu hamil dengan risiko preeklampsia di Puskesmas kabupaten Majalengka masih dalam batas normal , tetpi mempunyai kecendurungan untuk meningkat, Tekanan darah dikontrol oleh otak, sistem saraf otonom, ginjal, beberapa kelenjar endokrin, arteri dan jantung. Otak adalah pusat pengontrol tekanan darah di dalam tubuh. Serabut saraf adalah bagian sistem saraf otonom yang membawa isyarat dari semua bagian tubuh untuk menginformasikan kepada otak perihal tekanan darah, volume darah dan kebutuhan khusus semua organ. Semua informasi ini diproses oleh otak dan keputusan dikirim melalui saraf menuju organ-organ tubuh termasuk pembuluh darah, isyaratnya ditandai dengan mengempis atau mengembangnya pembuluh darah. Saraf-saraf ini dapat berfungsi secara otomatis(Hayens et al., 2003)-Para peneliti berpendapat bahwa preeklampsia merupakan suatu keadaan overaktivitas sistem saraf simpatis. Sistem saraf otonom dikenal sebagai regulator tekanan darah jangka pendek, namun terdapat kemungkinan untuk terjadi regulasi jangka panjang melalui gangguan sistem simpatis pada ginjal. Aktivitas sistem saraf simpatis pada preeklampsia lebih besar jika dibandingkan dengan wanita hamil normal. Peningkatan tahanan pembuluh darah tepi dan tekanan darah yang menandai preeklampsia dimediasi setidaknya sebagian oleh peningkatan aktivitas vasokonstriktor simpatis.

\section{Kecemasan}

Untuk kecemasan pada ibu hamil dengan risiko preeklampsia di puskesmas Kabupaten Majalengka sebagian besar 70 $\%$ ada pada kondisi kecemasan yang berat,dan $10 \%$ pada kondisi sangat berat, $15 \%$ berada pada kondisi kecemasan sedang dan $5 \%$ pada kondisi kecemasan ringan, ini sejalan dengan Hasil penelitian yang menunjukan bahwa $5,3 \%$ pasien dengan preeklampsia dan $0,7 \%$ dari non- 
preeklampsia menderita kecemasan yang sangat parah. (Kordi et al., 2017) Pada trimester pertama seorang ibu akan selalu mencari tanda-tanda untuk lebih meyakinkan bahwa dirinya hamil. Setiap perubahan yang terjadi pada tubuhnya akan selalu diperhatikan dengan seksama Reaksi psikologi dan emosional wanita yang pertama kali hamil ditunjukkan dengan adanya rasa kecemasan, kegusaran, ketakutan, dan kepanikan. Diantara mereka ada yang berpikiran bahwa kehamilan merupakan ancaman maut yang menakutkan dan membahayakan bagi diri mereka.(Hulliana, 2008) Trimester kedua sering disebut sebagai periode pancaran kesehatan, saat ibu merasa sehat. Quickening mungkin menyerang wanita untuk memikirkan bayinnya sebagai individu yang merupakan bagian dari dirinya. Pada trimester ini kecemasan yang terutama ialah kemungkinan cacat pada anaknya (Kusmiyati et al., 2009)

\section{Proteinuria}

Sedangkan untuk proteinuria sebagian besar sebanyak $75 \%$ ada dalam kondisi proteinuria yang negatif dan $25 \%$ dengan kondisi proteinuria negatif. Proteinuria didefinisikan terdapatnya protein dalam urin yang melebihi nilai normal yaitu lebih dari $150 \mathrm{mg} / \mathrm{hari}$ atau pada anak-anak lebih dari 140 $\mathrm{mg} / \mathrm{m} 2$. (Bawazier, 2006) Biasanya proteinuria baru dikatakan patologis bila kadarnya melebihi $200 \mathrm{mg} /$ hari pada beberapa kali pemeriksaan dalam waktu yang berbeda. Proteinuria persisten jika protein urin telah menetap selama 3 bulan atau lebih dan jumlahnya biasanya hanya sedikit dari atas nilai normal. ${ }^{\text {(Bawazier, 2006) }}$. Hasil pemeriksan proteinuria semua responden yang proteinurianya positip masuk dalam katagorik +1 yaitu kekeruhan ringan tanpa butiran, nilai proteinuria dengan dipstik jika (+1) adalah : $50 \mathrm{mg} / \mathrm{dl}$, belum sampai ada responden yang masuk katagori protein +2 ataupun +3 dan +4 baik pada responden kelompok intervensi maupun kelompok kontrol, +1 atau lebih tes dipsticksama dengan proteinuria $0,3 \mathrm{gram} / 24 \mathrm{jam}$ atau lebih, jika kondisi ini diikuti dengan tekanan darah $\geq 140 / 90 \mathrm{mmHg}$ yang terjadi setelah minggu ke 20 gestasi, maka responden sudah bisa didiagnosa preeklampsi, (Wagner, 2004)tetapi dari semua responden tidak ada yang tekanan darahnya $\geq 140 / 90 \mathrm{mmHg}$.

\section{Kesimpulan}

Terdapat ibu hamil dengan risiko preeklampsi di puskesmas kabupaten majalengka adalah sebagian besar $70 \%$ ada di kelompok umur 25-35 tahun, untuk pendidikan sebagian besar $65 \%$ ada pada kelompok pendidikn rendah, untuk status bekerja sebagian besar berada pada kelompok ibu tidak bekerja sebanyak $75 \%$, untuk pendapatan setengahnya $50 \%$ pada kelompok pendapatan $<1.5$ Juta,dan setengahnya $50 \%>1.5$ juta, untuk status paritas sebagian besar $60 \%$ ada pada kelompok multipara, untuk rata-rata tekanan sistolik 106,5 dan tekanan diastoliknya rata-rata 67,5 , untuk kecemasan sebagian besar $70 \%$ ada pada kondisi kecemasan yang berat, sedangkan proteinuria sebagian besar sebanyak $75 \%$ ada dalam kondisi proteinuria yang negatif.

\section{Daftar Pustaka}

ALIPOUR, M., FEIZI, Z., SEYEDFATEMI, N. \& HOSSEINI, F. 2006. Correlation between maternal anxiety during pregnancy and incidence of preeclampsia in primigravid women. Iran Journal of Nursing, 19, 79-88.

BAWAZIER, L. 2006. Proteinuria. Dalam: Sudoyo A, Setiyohadi B, Alwi I, Simadibrata M, Setiati S. Buku Ajar Ilmu Penyakit Dalam. Jilid III. Ed IV. Pusat Penerbitan Ilmu Penyakit Dalam Fakultas Kedokteran Universitas Indonesia. Jakarta, 519-523.

BLUME, T. W. 2006. Becoming a family counselor: A bridge to family therapy 
JURNAL ILMU KESEHATAN BHAKTI HUSADA:

HeAlth SCIENCES JOURNAL, Vol. 09 No. 02, DeSEMBER 2018

DOI: https://doi.org/10.34305/jikbh.v9i2.62

theory and practice, John Wiley \& Sons.

BURKE, M. T., CHAUVIN, J. C. \& MIRANTI, J. G. 2004. Religious and Spiritual Issues in Counseling: Applications Across Diverse Populations, New York, Taylor \& Francis.

CUNNINGHAM, F. 2010. leveno KJ, Bloom SL, Hauth JC, Rouse DJ, Spong CY. Abortion. William

CUNNINGHAM, F., LEVENO, K., BLOOM, S., SPONG, C. Y. \& DASHE, J. 2014. Williams Obstetrics, 24e, Mcgraw-hill.

DULEY, L., MEHER, S. \& ABALOS, E. 2006. Management of pre-eclampsia. BMJ: British Medical Journal, 332, 463.

HAWARI, D. 2005. Dimensi religi dalam praktek psikiatri dan psikologi, Fakultas Kedokteran, Universitas Indonesia.

HAYENS, B., FRANS, H. \& EDDY, S. 2003. Buku Pintar Menaklukkan Hipertensi. Jakarta: Ladang Pustaka dan Intimedia.

HKFM, P. 2016. Diagnosis Dan Tata Laksana Pre-Eklamsia.

HULliANA, M. 2008. Panduan menjalani Kehamilan sehat, Jakarta, Puspa Swara.

KHARAGHANI, R., GERANMAYE, M., JANANI, L., HANTOOSHZADE, S., ARBABI, M., BILANDI, R. R. \& BAGHERI, F. 2012. Preeclampsia and depression: a case-control study in Tehran. Archives of gynecology and obstetrics, 286, 249-253.

KHUSEN, D. 2016. Factors influencing maternal mortality from severe preeclampsia and eclampsia. Indonesian Journal of Obstetrics and Gynecology.

KHUZAIYAH, S., ANIES, A. \& WAHYUNI, S. 2016. Karakteristik Ibu Hamil Preeklampsia. Jurnal Ilmiah Kesehatan,

KORDI, M., VAHED, A., REZAEE TALAB, F., MAZLOUM, S. R. \& LOTFALIZADEH, M. 2017. Anxiety during pregnancy and preeclampsia: a case-control study. Journal of
Ciptaan disebarluaskan di bawah

Lisensi Creative Commons Atribusi-

NonKomersial-BerbagiSerupa 4.0

Internasional.

Midwifery and Reproductive Health, 5, 814-820.

KURKI, T., HIILESMAA, V., RAITASALO, R., MATTILA, H. \& YLIKORKALA, O. 2000. Depression and anxiety in early pregnancy and risk for preeclampsia. Obstetrics \& Gynecology, 95, 487-490.

KUSMIYATI, Y., WAHYUNINGSIH; \& HENI, P. 2009. Perawatan Ibu Hamil, Yogyakarta, Fitramaya.

MANUABA, P. D. I. B. G. 2010. Ilmu Kebidanan, Penyakit Kandungan \& Keluarga Berencana Untuk Pendidikan Bidan, Jakarta, EGC.

MOAFI, F., DOLATIAN, M., KESHAVARZ, Z., ALAVI MAJD, H. \& DEJMAN, M. 2013. Association between social support and maternal stress with preeclampsia. Social Welfare Quarterly, 13, 151-170.

PADILA 2014. Buku Ajar Keperawatan Maternitas.

REZAEE, R. \& FRAMARZI, M. 2014. Predictors of mental health during pregnancy. Iranian journal of nursing and midwifery research, 19, S45.

SHOLEH, M. 2006. Terapi Shalat Tahajud: Menyembuhkan Berbagai Penyakit, Jakarta: , Hikmah, PT. Mizan Publika.

TARAKESHWAR, N., HANSEN, N., KOCHMAN, A. \& SIKKEMA, K. J. 2005. Gender, ethnicity and spiritual coping among bereaved HIV-positive individuals. Mental Health, Religion \& Culture, 8, 109-125.

TEPPER, L., ROGERS, S. A., COLEMAN, E. M. \& MALONY, H. N. 2001. The prevalence of religious coping among persons with persistent mental illness. Psychiatric Services, 52, 660-665.

VOLLEBREGT, K. C., VAN DER WAL, M. F., WOLF, H., VRIJKOTTE, T. G., BOER, K. \& BONSEL, G. J. 2008. Is psychosocial stress in first ongoing pregnancies associated with preeclampsia and gestational hypertension? BJOG: An International Journal of Obstetrics \& Gynaecology, 115, 607-615.

WAGNER, L. K. 2004. Diagnosis and management of preeclampsia. Am Fam Physician, 70, 2317-24 
JURNAL ILMU KESEHATAN BHAKTI HUSADA:

HeAlth SCIENCES JOURNAL, Vol. 09 No. 02, DeSEMBER 2018

DOI: https://doi.org/10.34305/jikbh.v9i2.62 